\title{
Why Do They Stay: Factors Influencing Teacher Retention in Rural Zimbabwe
}

\section{Clifford Gomba}

University of the Incarnate Word, San Antonio, USA, cgomba@ @iwtx.edu

The attraction and retention of teachers in Zimbabwe is a problem not only unique to Zimbabwean schools, but all over the world. The problem is more pronounced in rural areas where resources are scarce, hence the tendency to repel teachers. Although the problem of teacher turnover is real, there are teachers who have remained in the profession for many years. The aim of the study is to find the factors that have influenced teachers to remain in teaching in rural Zimbabwe. Participants $(n=6)$ in the study were all practicing as teachers, having taught in the rural areas for at least ten years. Data was collected through interviews which were audio-taped and transcribed. The results from this basic interpretive qualitative study showed that teachers remained in the profession because of need to support their families, job security, unmarketable, support from colleagues and administration, and self-sacrifice leadership by principals.

Key Words: teacher attrition, teacher retention, self-sacrifice, Zimbabwe, turnover

\section{INTRODUCTION}

Retaining qualified and experienced teachers in the classroom has remained a challenge in the education sector for many years (Billingsley, 2004; Ingersoll, 2003; Perrachione, Rosser, \& Pertersen, 2008; Waddell, 2010). In some situations, qualified teachers who leave teaching do so to look for better opportunities in the private sector. Studies over the years have shown that most teachers who leave have fewer than ten years of teaching experience (Inman, 2004). Attrition has been found to be high in low-income and high minority schools (Donaldson, \& Johnson, 2011). In addition, research has also shown that younger teachers are more likely to leave the profession than older teachers (Billingsley, 2003; Ingersoll, 2001; Ingersoll, \& Kralik, 2004). In terms of gender, women were found to leave teaching more than their male counterparts (Guirano, Santibanaz, Dalay, \& Brewer, 2004). Studies have also shown that teacher turnover is more prevalent in Science and Mathematics as compared to other subject areas (Allen, 2005; Ingersoll, 2001; Kavanuke, 2013; Guirano, et al., 2004).

Why has teacher attrition and retention become important areas of concern in education? Teaching has been historically viewed as a low paying job suitable for women raising children (Ng \& Peter, 2009). Schools suffer from the 'revolving-door effect' (Ingersoll, 2004, p. 11) where schools are left unstable and lack continuity as qualified teachers

DOI: $10.12973 / \mathrm{iji} .2015 .825 \mathrm{a}$ 
leave and novice ones replace them (Donaldson \& Johnson, 2011). Changying (2007) put it aptly that "unqualified teachers produce unqualified students, who in turn become unqualified teachers" (p. 9) and the cycle becomes unbreakable. Any form of attrition or turnover may create talent crisis. Holbeche (2009) argued that talent crisis is created because times of selecting best candidates for a job are coming to an end, and is evidence of a dwindling growth in skills.

Efforts to reduce attrition should be based on an understanding of the factors that contribute to the teachers leaving the profession (Billingsley, 2003). Studies have shown that qualified teachers leave teaching because of low salaries, lack of administrative support, increased workloads, long working hours, and frustrations associated with trying to motivate apathetic students (Billingsley, 2004; Boe, Cook, \& Sunderland, 2008; Perrachione, et al., 2008). In addition, disruptive students, job dissatisfaction, uninvolved parents, invasive bureaucracy, family and personal circumstances, and the general lack of respect by both parents and students are some of the reasons why teachers leave teaching (AARP report, 2003; Inman, 2004; Williams, 2001). Inman (2004) added that dealing with students form diverse backgrounds, the need to be skilled in technology, cooperative learning, and a variety of specific instructional strategies are challenges that have led some teachers to leave teaching.

The issue of salaries as the cause of attrition has not been supported by research. Money and a challenging job were found to be factors that motivated employees to stay (Achiedu, \& Scott-Ladd, 2012; Holbeche, 2009). Teaching a challenging subject influenced teachers to stay in the teaching profession instead of pay (Marston, Courtney \& Brunnetti, 2006).

Kavenuke (2013) found that salary in the developing countries is an important factor in retaining qualified teachers. Teachers from low economic status remain in teaching not because they are satisfied and motivated, but because they need to survive (Kavenuke, 2013). If teachers do not get higher salaries they will leave the profession. Pay was an important determinant in whether to stay or not to stay for teachers (Anhorn, 2008; Nahal, n.d.). When asked what would convince them to return to the profession, former teachers mentioned increased salaries, less interference from administrators, tangible and recognition programs, and fewer standardized tests (AARP report, 2003).

\section{TEACHER RETENTION}

Concerns about teacher retention have focused on why teachers leave the profession, but much less attention has been given to those who stay especially the best (Perrachione, et al., 2008; Waddell, 2010; Williams, 2001). Research on why teachers remain in the profession is relatively scant (Perrachione, et al., 2008). Organizations (including education) should not focus only on strategic recruitment, but also on motivation and retention of the skilled workforce (Holbeche, 2009). The need to identify factors that cause teachers to remain in the profession is perhaps of great importance because of the need to plan effectively for the coming years (Inman, 2004). The reason why teachers stay is because they have found a school or community which has welcomed them, given them opportunities to grow, learn and use their talents to benefit those around them 
(Shyu, 2007). Employees are likely to stay if they are rewarded in monetary terms (Inman, 2004; Guirano, et al., 2004) and also if they are recognized and supported by their administrators and colleagues (Holbeche, 2009; Marston, et al., 2006; Shyu, 2007; Williams, 2001).

Despite the fact that teachers at both primary and secondary schools have been reported to swap their teaching profession for other high paying jobs, research has found that some teachers have remained (Inman, 2004). Teachers who have experienced satisfaction at their school and profession of teaching were likely to stay (Achiedu, \& Scott-Ladd, 2012; Perrachione, et al., 2008). Others have stayed because they care and love kids, enjoyed the job, genuine colleague support and also the feeling that they were making a difference (Marston, et al., 2006; Nahal, n.d.; Shyu, 2007; Williams, 2001). Ability to function independently in the classroom gives teachers who stay a sense of autonomy and control (Marston, et al., 2006; Williams, 2001). Those with a teacher certification are likely to stay as compared to those without (Allen, 2005).

It is interesting to note that teachers who stay are affected by the same conditions that contribute to their colleagues leaving the profession (Williams, 2001; Yost, 2006). Teachers who chose to stay are thus naturally resilient and persistent (Yost, 2006). Guirano, Santibanaz \& Daley (2006) argue that those who enter teaching and stay do so because teaching would have become the most attractive profession to pursue in comparison to other professions available to them. In other words they had to stay on the job not because they liked it, but because they had to pay bills (Shyu, 2007). Some teachers may stay in teaching as a way to bypass longer preparation programs, licensing requirements, or the bureaucratic obstacles associated with landing a teaching job especially in large, urban district (Donaldson \& Johnson, 2011).

\section{Teacher Retention in Zimbabwe}

Teacher retention in Zimbabwe has been a major concern in recent years. There is paucity of information on the subject except documents and reports from Ministry of Education. However, according to the Ministry of Education (2008) teacher attrition was felt in Sciences and Mathematics as teachers left for neighboring countries, especially in South Africa where they are in demand. The government is unable to match what South Africa pays its teachers. The result was mass exodus of teachers (UNICEF, 2008) to other countries and the private sector. Those teachers who were hired to replace those who had left were not as good as their predecessors (Billingsley, 2004). The government of Zimbabwe is committed to keep its teachers through paying competitive salaries, but agrees to the fact that there is nothing they can do to stop mass exodus of teachers to other countries (Ministry of Education, 2008).

Further it has been reported in the media that Namibia is planning to recruit Zimbabwean teachers. The reason why Namibia requires more teachers is because of increased student enrolment (Muleya, 2013). The report quoted the permanent secretary in the Ministry of Information and Communication Technologies, Mr. Ndjarakana saying Zimbabwe was "identified (because of its) exceptional human capital development from which Namibia can tap on their expertise" (Muleya, 2013). Faced 
with this threat to its teachers, Zimbabwe should therefore increase teachers' salaries as a way to increase teacher retention (Greiner, \& Smith, 2009). However, there are rich private schools that have managed to keep their teachers by paying them higher salaries and incentives (Ministry of Education, 2008).

It is against this background that it became necessary to find out why some teachers remained in the profession despite the fact that others were leaving. Why did they remain, when some were going to other countries and private sectors for greener pastures?

\section{Purpose of the Study}

The purpose of this study was to identify factors that have influenced teachers who have taught for more than ten years to remain in teaching despite the fact that some were leaving due to bad economic conditions in Zimbabwe.

\section{METHODS}

\section{Design}

This qualitative study was done using the basic interpretive qualitative study to discover and understand teachers' perspectives, (Merriam, 2012) so as to inform rural retention methods and process. The reason for using this approach in doing this qualitative research is because the researcher is interested in discovering and understanding how teachers in the study make meaning of their continued teaching experience.

\section{Participants}

At the time of the research, all the participants were Zimbabwean trained qualified teachers teaching in the rural area of Chilimanzi in the Midlands province. Participants $(n=6)$ were selected from three rural secondary schools with more than ten years teaching experience. Of the 6 participants, 4 were males, and the remaining 2 were females. The teachers willingly took part in the study and were chosen from three boarding schools. The sampling procedure that was chosen to select the participants was purposive sampling. For the purposes of privacy and anonymity, pseudonyms have been used throughout this research paper.

Table 1: Demographic Characteristics of respondents $(\mathrm{n}=6)$

\begin{tabular}{llllll}
\hline Name & Gender & Marital Status & Age group & Qualification & Years taught \\
\hline Craig & Male & Married & $55-60$ & Diploma & 30 \\
\hline David & Male & Married & $50-55$ & Diploma & 23 \\
\hline Peter & Male & Widowed & $50-55$ & Diploma & 26 \\
\hline Cecelia & Female & Married & $40-45$ & Diploma & 13 \\
\hline Justin & Male & Married & $60-65$ & Certificate & 40 \\
\hline Patience & Female & Married & $30-35$ & Bachelor's & 11 \\
\hline
\end{tabular}

\section{Data Collection}

Upon obtaining the Institutional Review Board (IRB) approval and the signing of the consent form by the participants, data was collected through interviews. Data was collected mainly through interviews and the length varied from 30 to 40 minutes. Two 
interviews were conducted in vernacular (Shona language) and subsequently translated to English by the researcher. The remaining four interviews were done in English. All the interviews were conducted at the school site by the researcher and consisted of openended questions. Probing questions were also used to gather more information if it was felt the participant did not express to the satisfaction of the researcher. All the six interviews were audiotaped and transcribed (Ryan \& Bernard, 2000).

\section{Data Analysis}

As previously stated, all data collected was analyzed inductively to identify the recurring common themes that were identified within the data. A rich, descriptive account of the findings is presented and discussed, using references to the literature that framed the study (Merriam, 2012). Before the analysis of data, the data was reviewed to obtain the general sense of the material (Creswell, 2012). A hand analysis of data was done because the data analyzed comprised of a small database (Creswell, 2012). Preliminary themes were identified, and were compared to find common themes found in the data (Charmaz, 2002). A colleague who had trained in qualitative study carried a peerdebriefing to ensure the completeness of data analysis test.

\section{RESULTS}

The results from the study showed that teachers had various reasons for remaining in teaching for a period for more than 10 years. The data analysis procedure showed six reasons why teachers choose to remain in teaching despite others leaving. The themes that emerged were self-sacrifice principal, family, fear of the unknown, job security, unmarketable because of age, and administration and colleague support. One of the teachers identified support of the administration, and also hopes for the better in future in terms of remuneration. The themes do not show job satisfaction as a reason for staying in the profession.

\section{Self-sacrifice principal (head)}

One of the dominant themes that came from the interviews is what Ruggieri and Abbate (2013) called self-sacrificial leadership. Teachers at all the three schools mention the aspect of the presence of a principal who sacrificed his/her resources for the betterment of the teachers and the school. The context of sacrifice differed, but the concept was of a head that goes out of his/her way to use resources that may not be meant for teachers, for the benefit of all teachers at the school.

"This school has less gossip. I transferred to this school because the head is good with teachers. He sacrifices his time and energy for the betterment of the school and also us teachers. He gave us incentives ... one time but did not give himself the money because he said the school coffers were dry." (Patience)

"I wouldn't be here if the head was stingy. He supports us ... sacrifices his time and personal monetary resources to make sure the school and teachers are happy. ... he used his car for school business without demanding payment." (Justin) 
"The head understands ... one time he spent most of his time doing school business. When he came back he did give himself incentive, but went on to work extra-ordinary hours. We believe it was on school business. That's a lot of sacrifice ... and cannot be done by anyone." (Craig)

Family

The issue of family emerged as one of the dominant themes of the study. The teachers were fond of their families that they could not leave for they feared that no one would look after their family. With respect to women, their husbands influenced them to stay. Children, spouses and other extended family members influenced the teachers to remain in teaching, as reflected by the following quotes:

"I have 3 young kids. Who would look after them when I go to look for (another) job? Besides my husband wouldn't allow it ... you know our culture. My husband and the kids are the reason why I am still teaching." (Cecelia)

"I get educational support for my kids ... and I don't know of any job that would in that regard, support me when I leave teaching. My husband would have none of it (leaving teaching). He thinks I may have a boyfriend." (Patience)

"My mother, wife and kids depend on me and cannot afford to go out and look for job. Who would feed them when I am away ... and worse if I fail to get a job?" (Peter)

Teachers stressed the importance of their families in deciding to stay. They believed that fellow teachers also stay because they have family and relatives who depend on them. The participants reiterated that, although the economy is bad, they are better off teaching than not doing anything. Some of the participants remained in teaching because they teach at the same school with their spouses, and would not risk teaching in looking for another job that will definitely result in them leaving apart.

\section{Fear of the unknown}

The teachers believed that the economy as a whole is depressed and they cannot find better opportunities outside teaching. The teachers generally felt that even if they were to leave teaching, there would be nothing for them. They expressed fear of what would happen if they leave their guaranteed job. They preferred to transfer from their current school to another school rather than leave the teaching profession altogether.

“Aah, I don't know anyone out there, and I cannot just go. If the job offer fails to materialize after I have resigned teaching, what would happen?" (David)

"I would fail to get any job offer, so I just stick with what I have. Besides I am old." (Justin)

"The world out there is not kind. Today you have a good job, and tomorrow you are dismissed ... in teaching you only get dismissed when you have improper association with kids." (Peter) 
"I went to South Africa, hoping to get a job before I get a job before I got married, and ended up sleeping in the open. The world out there is not what you think it is." (Patience)

The teachers added that if they were to leave teaching at their schools, they would go to a boarding school due to the incentives being offered. They identified the schools they would likely go to in the effect that they leave their current schools. They would not leave to go into the private sectors.

Job security

Teachers expressed willingness to stay in teaching because their jobs are generally secure as compared to the private sector. That is the reason they chose teaching and that is the reason they are still teaching. They argued that they have never heard of a school that closed, and teachers became jobless. It is in the private sector where companies close, and workers retrenched and become jobless.

"I have been in teaching for many years, and my brother in the private sector has changed jobs many times ... and did not get any benefit. That is why I remain in teaching. No one will fire or fine me ... unless I have an improper relationship with a student." (David)

"After I retire, I will be paid monthly pension for the rest of my life. Many jobs in this country do not have that kind of facility. Teaching is the only secure job in Zimbabwe." (Justin)

"I have not been charged, but here I am still teaching. If it were any other job I would have charged, suspended or even discharged, but since it is in teaching I am still here." (Patience)

"I have not heard any person who said they have been fired from teaching. We are here to stay." (Peter)

\section{Unmarketable}

The teachers interviewed believed that they are no longer marketable in the private sector because of age and also the qualification they hold. Most of the teachers believed that they are too old to look for another job. Besides, they cannot afford to go back to school to get higher qualifications as this would be waste of time.

"Who would employ an old man like me in the private sector? I am old and my place is teaching." (Justin)

Thirty years of teaching is not a joke. In those years, I have never compromised my job on any day. I am unable to do any other job besides teaching." (Craig)

"No one will hire an old person. If it was in marketing, I would repel customers." (Peter)

The teaching qualifications made it practically impossible for them to even think of quitting a job because no one would hire them in the private sector outside teaching. 
Participants with a teaching diploma and who consider themselves as older posited that they are too old to learn and upgrade themselves and get a job outside teaching. One female participant felt that teaching was very accommodative as women are allowed to go on maternity leave for three months.

\section{Administration and colleague support}

Administration and colleague support is one of the reasons some teachers felt that they are still at the same school for a long time. Teachers believed that the administration would help them resolve classroom problems in times of distress. Social support was also seen as a major reason for remaining in the profession, especially at the same school for a long time.

"Thirty years, being at the same school is not a joke. Successive administrators have been there for us. You are (always) with teachers that support you and help you out both professionally and socially. We are like a family here. That's what I like about teaching at a boarding school." (Justin)

"When I lost my mother, all teachers came to support me emotionally, and they gave (me) financial assistance. I felt they were my brothers and sisters, and not workmates. We are now a family here, and I don't want to leave this school." (Patience)

Only one teacher believed that the other reason she has remained in teaching is because she loved the job (Perrachione et al., 2008) and is satisfied being the teacher. Salary seems not to a contributing factor for the teacher to remain in the profession.

"I wouldn't imagine myself working any other job besides teaching. I want money ... as little as it is, I would not be a teacher if I wanted money only. I am happy being a teacher ... at a boarding school. I love the job." (Cecelia)

\section{DISCUSSION}

The purpose of this study was to find why teachers in the rural areas of Zimbabwe remain in teaching when others have left. From interviews with six rural Zimbabwean high school teachers, at boarding schools, it was discovered that family, job security, fear of the unknown and being unmarketable were reasons why teachers chose to remain in teaching.

Participants in this study cited family issues as the major reason for them to remain in the teaching field for more than ten years. All teachers in this study had family and relatives to look after. This study contributes to the body of literature in finding why teachers remain in teaching. This is because no previous research has been found that support family as a reason for teachers staying in the teaching profession. In fact Inman (2004) and Williams (2001) found that some teachers had left teaching due to family and other personal reasons. Younger women were found to leave the profession due to marriage (Guirano, et al., 2004), pregnancy and child bearing (Allen, 2005). This is opposed to the findings of the study as women were found to stay in teaching because of family-related situations. 
The response to the open-ended questions showed that teachers were mostly concerned with external factors (family, fear of the unknown, job security and unmarketable) instead of the internal factors (having to do with the job directly). Billingsley, (2003) Ingersoll, (2004) Shyu, (2007) and Waddell (2010) found that internal factors (relationship with coworkers, administration support, job satisfaction, and working with students) are some of the reasons why teachers remain in teaching. The results from this research build on a growing body of literature that employees in general are no longer loyal to employers (Holbeche, 2009). This is because many of them presume that their carrier prospects have been disrupted by continuous organizational restructurings. With this line of thinking it is therefore argued through the results of this study that employees may find it increasingly necessary to keep their jobs because they have responsibilities to look after, and not for the love of the job.

Contrary to beliefs by the Ministry of Education, Sports and Culture (2007), that rural teachers also want to teach in urban areas, this study found that teachers actually preferred to teach in the rural boarding schools. The reasons are mainly centered on a generally cheaper lifestyle as most concurred that they do not pay rent, electricity and water bills. In addition they are given extra pay as incentive for them to remain in schools (UNICEF, 2008). The teachers also felt that due to qualifications they held, it was better for them to remain in the rural areas where competition for teaching places was non-existent.

Most studies have shown that money alone is not an important motivational factor for employees to stay on the job (Billingsley, 2004; Ingersoll, 2003; Holbeche, 2009; \& Perrachione, 2008). The study found that participants considered salary as a contributing factor for remaining in teaching, and incentive (additional pay paid by the school) as a specifically the reason for teaching at their present schools. According to the AARP (2003) report, former teachers said that they would return to teaching if there were offered an increased pay. Inman and Marlow (2004) found that salary was a major factor for teachers staying in teaching.

The teachers in the study perceived job security as the main factor for remaining in the teaching profession for more than ten years. The teachers said that as long as they performed their work diligently and avoid improper association with students, then their job is secured. Job security was found to be a factor for the novice as well as experienced teachers to remain in the profession (Inman, \& Marlow, 2004).

\section{CONCLUSIONS AND RECOMMENDATIONS}

Many factors found in this study may be essential in ensuring that teachers remain in teaching. The results showed that teachers who have remained in teaching do not have any other qualifications besides teaching. Those with teacher certification are likely to stay as compared to those without (Allen, 2005). It is important to satisfy qualified and experienced teachers through the increase of their salaries. The fact that they are no longer marketable outside teaching and that chances of them leaving are low, should not be used a way to pay them lowly or to treat them unfairly. Although the teachers lamented the love for teaching as their initial reason for joining the profession, however, 
they no longer hold the same view (except one teacher) as low pay has reduced them to beggars. So there seems to be an intricate relationship between salaries and teacher retention. Higher salaries were associated with lower teacher retention, and low salaries were the reason for teachers leaving the profession (Guirano, et al., 2004).

Another concern that came up in the study is the issue of family connections. Government policy concerning this issue is that spouses are given first priority if they want to transfer to their spouse's school (Ministry of Education, 2007). It is therefore recommended that government should ensure that those teachers who need to transfer and teach closer or together with their spouses, are afforded the chance. From this study it was found that spouses who are teaching at the same school consider staying in the profession longer or forever.

Meyers (2003) suggested that to avoid conflict in the classroom, a teacher should employ strategies such as increasing collaboration and building communities of learning. In the same vein, it is recommended that administrators may also promote collaboration among their teachers through modeling their behavior. In addition they may also help build communities of teaching which in turn create a sense of family and belongingness.

Administrators need to support their teachers as a way of keeping them in the profession. Maybe it is time for administrators to embrace an emerging leadership concept of self-sacrifice leadership. Ruggieri and Abbate (2013) found that selfsacrificial leaders are prepared to abandon everything including personal gains, privileges or enrichment for the betterment of the organization. In fact, these types of leaders may use their own resources such as their private time to perform tasks for the organization. The authors propose that followers who have self-sacrificial leaders tend to rate them as effective, legitimate and charismatic. It is thus proposed through this study that administrators in education should embrace the self-sacrificial leadership style that will result in followers (teachers) trying to imitate their leaders and the organization (schools) will be successful.

The study has been limited to teachers in a rural area of Zimbabwe in the Midlands province, and hence may not be applicable to teachers in urban areas. The teachers who participated in the study all taught at private boarding schools, and this might not be reflective of teachers who teach at rural council and government schools. The study was limited to one rural district and its generalization to other districts may not be possible. The author's sample is too small, hence not conclusive enough to generalize the status of teachers' reasons for staying in the profession.

However, the study is valuable for it adds value to the body of literature concerning teacher retention. It is not the teachers' choice to remain in teaching, but the uncertainty of life outside teaching that influenced them to stay. So in order to ensure that these teachers stay and love their jobs, competitive salaries that match or even surpass those in private sector should be considered. Teachers should be able to regard teaching, not as a stepping-stone to a better carrier, but a dream job.

\section{REFERENCES}


AARP, (2003). Exodus: A study of teacher retention in America: 50 who stayed - 50 who left. Retrieved from http://assets.aarp.org/rgcenter/general/exodus.pdf

Allen, B. M. (2005). Eight questions on teacher recruitment and retention: What does the research say? Education Commission of the States, 1-145.

Anhorn, R. (2008). The profession that eats its young. The Delta Kappa Gamma Bulletin.74(3), 15-26.

Ashiedu, A. J., \& Scott-Ladd, D. B. (2012). Understanding Teacher Attraction and Retention. Australian Journal of Teacher Education, 37(11), 17-35.

Billingsley, S. B. (2003). Special Education Teacher Retention and Attrition: A Critical Analysis of the Literature. Journal of Special Education, 38(1), 39-55.

Billingsley, S. B. (2004). Special education teacher retention and attrition: A Critical Analysis of the Research Literature. The Journal of Special Education, 38(1), 39-55.

Boe, E. E., Cook, H. L., \& Sunderland, J. R. (2008). Teacher turnover: Examining exit attrition, teaching area transfer, and school migration. Exceptional Children, 75(1), 731 .

Changying, W. (2007). Analysis of teacher attrition. Chinese Education and Society, 40(5), 6-10.

Charmaz, K. (2000). Grounded theory: Objectivist and constructivist methods. In N. Denzin \& Y. Lincoln (Eds.), Handbook of qualitative research (2nd ed.) (pp. 509-536). Thousand Oaks, CA: SAGE Publications.

Creswell, W. J. (2012). Educational research: Planning, conducting, and evaluating qualitative and quantitative research. Boston, MA: Pearson.

Donaldson, M. L. \& Johnson, S. M. (2011). Teach for America teachers: How long do they teach? Why do they leave? Phi Delta Kappa, 93(2), 47-51.

Ewing, R., \& Manuel, J. (2005). Retaining quality early career teachers in the profession: New teacher narratives. Change. Transformations in Education, 8(1), 1-16.

Greiner, S.C., \& Smith, B. (2009). Analyses of selected specific variables and teacher attrition. Education, 129(4), 579-584.

Guarino, et al., (2004). A review of the research literature on teacher recruitment and retention (TR-164-EDU). Santa Monica, CA: RAND.

Guarino, et al., (2006). Teacher recruitment and retention: A review of the recent empirical literature. Review of Educational Research, 76, 173-208.

Holbeche, L. (2009). Aligning human resources and business strategy. London, Great Britain: Elsevier. 
Ingersoll, R. M. (2001). Teacher turnover, teacher shortages, and the organization of schools (No. R-01-1). Seattle: University of Washington, Center for the Study of Teaching and Policy.

Ingersoll, R., \& Kralik, M. J. (2004). The Impact of mentoring on teacher retention: What the research says. GSE Publications, 1-24.

Inman, D., \& Marlow, L. (2004). Teacher retention: Why do beginning teachers remain in the profession? Education 124(4), 605-614.

Joiner, S., \& Edwards, J. (2008). Novice teachers: Where are they going and why don't they stay? Journal of Cross-Disciplinary Perspectives in Education, 1(1), 36 - 43.

Kavenuke, P. (2013). What is it that keeps good teachers in the teaching profession: A reflection on teacher retention. SAVAP International, 4(1): 165-175.

Marston, et al., (2006). The voices of experienced elementary teachers: Their insights about the profession. Teacher Education Quarterly, 111-131.

Merriam, S. B. (2012). Introduction to qualitative research. In S. B. Merriam and Associates, Qualitative research in practice: Examples for discussion and analysis (pp.3-17). San Francisco, CA: Jossey-Bass.

Meyers, A. S. (2003). Strategies to prevent and reduce conflict in college classrooms. College Teaching, 3(51), 94-98.

Ministry of Education. (2008). National report on the status of education by Zimbabwe. Retrieved from http://www.ibe.unesco.org/National_Reports/ICE_2008/zimbabwe_NR08.pdf.

Ministry of Education. (2007). Report on the development and state of the art of adult learning and education in Zimbabwe. Retrieved from http://www.unesco.org/fileadmin/MULTIMEDIA/INSTITUTES/UIL/confintea/pdf/Nati onal_Reports/Africa/Africa/Zimbabwe.pdf.

Muleya, T. (2013, December, 13). Zimbabwe: Namibia to Recruit Zim Teachers. All Africa. Retrieved from http://allafrica.com/stories/201312120121.html.

Nahal, P. S. (n.d). Voices from the Field: Perspectives of First-year Teachers on the Disconnect between Teacher Preparation Programs and the Realities of the Classroom. Research in Higher Education Journal, 1-19.

Ng, C. J., \& Peter, L. (2010). Should I stay or should I go? Examining the career choices of alternatively licensed teachers in urban schools. Urban Review, 42(2), 123142 .

Perrachione, et al., (2008). Why do they stay? Elementary teachers' perceptions of job satisfaction and retention. The Professional Educator, 32(2).

Ruggieri, S. \& Abbate, S. C. (2013). Leadership style, self-sacrifice, and team identification. Social Behavior and Personality, 7(41), 1171-1178. 
Ryan, G., \& Bernard, R. (2000). Data management and analysis methods. In N. Denzin \& Y. Lincoln (Eds.), Handbook of qualitative research (2nd ed.) (pp. 769-802). Thousand Oaks, CA: SAGE Publications.

Shyu, J. (2007). Responses wanted: Why do teachers stay? New Terrain. Retrieved from http://blogs.edweek.org/teachers/new_terrain/2007/07/why_do_teachers_stay_1.html

UNICEF. (2008). Education statistics: Zimbabwe. Division of policy and practice, statistics and monitoring section. Retrieved from http://www.childinfo.org/files/ESAR_Zimbabwe.pdf.

Waddell, H. J. (2010). Fostering Relationships to Increase Teacher Retention in Urban Schools. Journal of Curriculum and Instruction, 4(1), 70-85.

Yost, S. D. (2006). Reflection and Self-Efficacy: Enhancing the Retention of Qualified Teachers from a Teacher Education Perspective. Teacher Education Quarterly, 59-76.

\section{Appendix A}

1. Describe your experience working as a teacher.

2. Why did you become a teacher?

3. When and how did you obtain your teaching certificate?

4. Why do you work at this school?

5. Why have you decided to remain in teaching for more than ten years?

6 . What would make a person want to become a teacher?

7. What do you enjoy most about teaching?

8. What is your philosophy of education?

9. Is education important to you? Why?

10. How would the administration describe you as an educator?

11. How would your colleagues describe you as an educator?

12. What do you think motivates a person to excel in the classroom?

13. What are the kinds of challenges you face as a teacher?

14. What kind of in-service training have you received in your teaching career?

15. Do you expect to leave teaching, and if so when and why?

16. Do you have anything that you would want to share with me about your teaching?

\section{Turkish Abstract}

Neden Kalırlar: Kırsal Zimbabwe’de Öğretmenlerin İşten Ayrılmalarını Etkileyen Faktörler

Öğretmenler için işin çekiciliği ve işi bırakma sadece Zimbabwe'deki okullara has bir problem değil tüm dünyada problemli bir konudur. Problem kaynakların kıt olduğu kırsal kesimlerde daha da telaffuz edilir. Öğretmenlerin eksilmesi sorunu gerçek olmasına rağmen mesleğinde uzun yıllar kalan öğretmenler de vardır. Çalışmanın amacı kırsal kesimdeki bu öğretmenlerin neden öğretmenliğe devam ettiklerini etkileyen faktörleri ortaya çıkarmaktır. Çalışmaya katılanlar ( $\mathrm{n}=$ 6) kırsal bölgede en az 10 yıldır öğretmenlik yapan öğretmenlerdir. Veriler kayıt altına alınan ve kodlanan görüşmelerle toplanmıştır. Çalışmanın sonuçları öğretmenlerin kalma sebepleri olarak 
ailelerini destekleme ihtiyacı, iş güvenliği, iş arkadaşlarından ve yöneticilerden destek, müdürlerin öz-fedakarlık liderliği sayılabilir.

Anahtar Kelimeler: öğretmen yıpranması, öz-fedakarlık, Zimbabwe, eksilme

\section{French Abstract}

\section{Pourquoi Ils Restent: Facteurs Influençant Rétention de Professeur au Zimbabwe Rural}

L'attraction et la rétention de professeurs au Zimbabwe sont un problème non seulement unique aux écoles Zimbabwéennes, mais dans le monde entier. Le problème est plus prononcé dans des zones rurales où les ressources sont rares, d'où la tendance de repousser des professeurs. Bien que le problème de chiffre d'affaires de professeur soit reel, il y a les professeurs qui sont restés dans la profession depuis de nombreuses années. Le but de l'étude est de trouver les facteurs qui ont influencé des professeurs pour rester dans l'enseignement au Zimbabwe rural. Les participants (n =6) dans l'étude tous pratiquaient comme des professeurs, ayant enseigné dans les zones rurales pendant au moins dix ans. Les données ont été rassemblées par les entretiens qui ont été enregistrés sur bande magnétique et transcrits. Les résultats de cette étude qualitative interprétative de base ont montré que les professeurs sont restés dans la profession à cause du besoin de supporter(soutenir) leurs familles, sécurité de l'emploi, invendable, le support de collègues et l'administration et la direction de sacrifice de soi par des principaux.

Mots Clés: attrition de professeur, retention de professeur, sacrifice de soi, le Zimbabwe, chiffre d'affaires

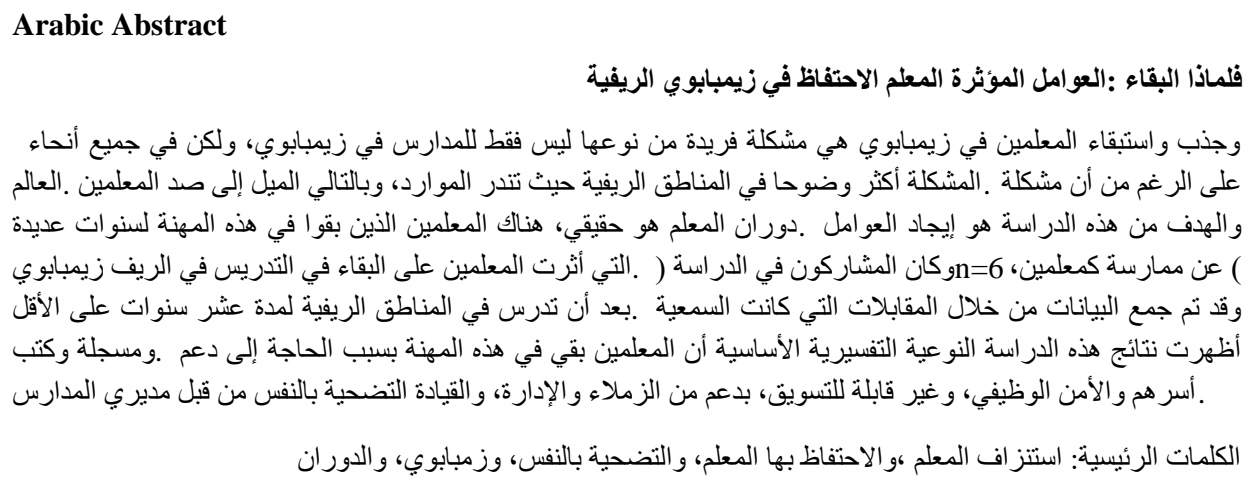

